\title{
Thalassospira xianhensis sp. nov., a polycyclic aromatic hydrocarbon-degrading marine bacterium
}

\author{
Correspondence \\ Hui Wang \\ wanghui@tsinghua.edu.cn
}

\author{
Baisuo Zhao, Hui Wang, Ruirui Li and Xinwei Mao \\ Department of Environmental Science and Engineering, State Key Joint Laboratory on \\ Environmental Simulation and Pollution Control, Tsinghua University, Beijing 100084, PR China
}

\begin{abstract}
A polycyclic aromatic hydrocarbon-degrading marine bacterium, designated strain $\mathrm{P}-4^{\top}$, was isolated from oil-polluted saline soil in Xianhe, Shangdong Province, China. Strain $\mathrm{P}-4^{\top}$ was Gram-negative-staining with curved to spiral rod-shaped cells and grew optimally with 3-6\% $(\mathrm{w} / \mathrm{v}) \mathrm{NaCl}$ and at $30{ }^{\circ} \mathrm{C}$. The predominant fatty acids were $\mathrm{C}_{18: 1} \omega 7 \mathrm{c}(35.0 \%), \mathrm{C}_{16: 0}(25.0 \%)$, $\mathrm{C}_{16: 1} \omega 7 c(17.9 \%), \mathrm{C}_{14: 0}(6.2 \%)$ and $\mathrm{C}_{17: 0}$ cyclo $(5.2 \%)$. The major respiratory quinone was Q-9 and the genomic DNA G +C content was $61.2 \pm 1.0$ mol\%. Phylogenetic analysis based on the 16S rRNA gene sequence indicated that strain $\mathrm{P}-4^{\top}$ belonged to the genus Thalassospira of the class Alphaproteobacteria. DNA-DNA hybridization with Thalassospira xiamenensis DSM $17429^{\top}$ showed relatedness of $36.0 \%$, and lower values were obtained with respect to other Thalassospira species. Based on physiological and biochemical tests and 16S rRNA gene sequence analysis as well as DNA-DNA relatedness, strain $\mathrm{P}-4^{\top}$ should be placed in the genus Thalassospira within a novel species. The name Thalassospira xianhensis sp. nov. is proposed, with $\mathrm{P}-4^{\top}\left(=\mathrm{CGMCC} 1.6849^{\top}=\mathrm{JCM} 14850^{\top}\right)$ as the type strain.
\end{abstract}

Polycyclic aromatic hydrocarbons (PAHs) are hydrocarbons that consist of two or more fused aromatic rings (Habe \& Omori, 2003; Hedlund \& Staley, 2001). PAHs are released into the marine environment as a result of various anthropogenic activities such as marine seepage and accidental discharges during the transport and disposal of petroleum products and the use of fossil fuels (Sohn et al., 2004). Some PAHs are highly carcinogenic, genotoxic and cytotoxic to marine organisms and may be transferred to humans through seafood consumption (Menzie et al., 1992). Therefore, removal of PAHs from contaminated marine environments is of considerable importance.

Several PAH-degrading strains have been isolated from PAH-contaminated marine sediments (Hedlund \& Staley, 2001; Kwon et al., 2005; Sohn et al., 2004). In this study, we report the characterization of a $\mathrm{PAH}$-degrading marine bacterium that was isolated from saline soil contaminated with crude oil in Xianhe, Shangdong Province, China.

To isolate PAH-degrading bacteria, $5 \%$ sea-salt defined medium (5\% SSDM; Zhao et al., 2009) and 5\% SSDM with $0.5 \%$ yeast extract ( $5 \%$ SSDMY) were used. Solid $5 \%$ SSDMY medium was prepared with $1.5 \%$ agar. A sample

Abbreviation: $\mathrm{PAH}$, polycyclic aromatic hydrocarbon.

The GenBank/EMBL/DDBJ accession number for the $16 \mathrm{~S}$ rRNA gene sequence of strain $\mathrm{P}-4^{\top}$ is EU017546.

Tables showing fatty acid contents and DNA-DNA relatedness values between strain $\mathrm{P}-4^{\top}$ and the type strains of Thalassospira species are available as supplementary material with the online version of this paper. of oil-polluted saline soil $(1 \mathrm{~g})$ was added to $100 \mathrm{ml} 5 \%$ SSDM medium supplemented with phenanthrene $(100 \mu \mathrm{g}$ $\mathrm{ml}^{-1}$ ) in a $300 \mathrm{ml}$ Erlenmeyer flask. The culture was aerobically incubated at $30{ }^{\circ} \mathrm{C}$ in darkness on a rotary shaker operating at 200 r.p.m. After 2 weeks, $10 \mathrm{ml}$ culture was transferred to $100 \mathrm{ml} 5 \%$ SSDM medium and incubated under the conditions described above. The enrichment was performed five or six times. Next, a culture broth dilution series was spread on $5 \%$ SSDMY agar. After incubation for 2 days, single colonies were picked and cultivated in $5 \mathrm{ml} 5 \%$ SSDM using phenanthrene as the sole source of carbon and energy. These isolates developed a yellowish-orange or reddish-brown colour, which is an indication of ring cleavage of PAH compounds (Guerin \& Jones, 1988; Kasai et al., 2002) and, thus, phenanthrenedegrading activity. After purification by restreaking, one of the representative isolates, strain $\mathrm{P}-4^{\mathrm{T}}$, was found to have relatively low $16 \mathrm{~S}$ rRNA gene sequence similarity (98.0\%) to Thalassospira lucentensis DSM $14000^{\mathrm{T}}$ (López-López et al., 2002) in the genus Thalassospira of the class Alphaproteobacteria, and this strain was selected for further studies.

Cell morphology was examined by scanning electron microscopy as described by Acinas et al. (1999). Negatively stained cells with $1.0 \%(\mathrm{w} / \mathrm{v})$ phosphotungstic acid were used for the observation of flagella with a Zeiss DSM 960 transmission electron microscope. Gram staining was carried out by using the standard Gram reaction and the result was confirmed by the $\mathrm{KOH}$ test (Baron \& Finegold, 1990). The $\mathrm{NaCl}$ requirement for growth was 
tested using 5\% SSDMY medium with $\mathrm{NaCl}$ concentrations ranging from 0 to $20 \%(\mathrm{w} / \mathrm{v})\left(\mathrm{pH} 7.2,30{ }^{\circ} \mathrm{C}\right)$. The effects of $\mathrm{pH}$ and temperature on growth were determined using $5 \%$ SSDMY medium at $\mathrm{pH} 4.0-10.0\left(30{ }^{\circ} \mathrm{C}\right)$ and by incubation at $4-50{ }^{\circ} \mathrm{C}(\mathrm{pH} 7.2)$. After incubation at $30{ }^{\circ} \mathrm{C}$ for 2 days on $5 \%$ SSDMY agar, strain $\mathrm{P}-4^{\mathrm{T}}$ formed small, cream-yellow, opaque, circular and convex colonies with flat edges. Cells were Gram-negative-staining, curved- to spiral-shaped rods, $1.0-1.6 \mu \mathrm{m}$ long and $0.3-0.6 \mu \mathrm{m}$ wide (Fig. 1). No flagellum or motility was observed. Strain P-4 ${ }^{\mathrm{T}}$ grew in $5 \%$ SSDMY broth containing $0.1-17.0 \% \mathrm{NaCl}$ (optimum 3.0-6.0\%). The temperature range for growth was $10-42{ }^{\circ} \mathrm{C}$ (optimum $30{ }^{\circ} \mathrm{C}$ ). The $\mathrm{pH}$ range for growth was $\mathrm{pH}$ 5.5-9.0 (optimum $\mathrm{pH}$ 7.2).

Catalase activity was tested by assessing bubble production in a $3 \%$ hydrogen peroxide solution. Oxidase activity was determined by the oxidation of $1 \% p$-aminodimethylaniline oxalate. Production of urease was tested as described by Cowan \& Steel (1965). Hydrolysis of starch, Tween 80 and DNA was determined on 5\% SSDMY agar with concentrations of substrates described by Cowan \& Steel (1965) and Lányí (1987). Facultatively anaerobic growth was tested with pyruvate $(20 \mathrm{mM})$ as the carbon source and nitrate $(10 \mathrm{mM})$, nitrite $(5 \mathrm{mM})$, sulfate $(20 \mathrm{mM})$, fumarate $(20 \mathrm{mM})$, ferric iron $(50 \mathrm{mM})$ or $\mathrm{MnO}_{2}$ $(10 \mathrm{mM})$ as the electron acceptor. Nitrate and nitrite reduction were assessed as described by Lányí (1987). Denitrification was tested by growing strain $\mathrm{P}-4^{\mathrm{T}}$ anaerobically in the presence of nitrate (Zumft, 1992). For acid production from carbohydrates, bromcresol purple was added to a final concentration of $0.03 \mathrm{~g} \mathrm{l}^{-1}$. The ability of strain $\mathrm{P}-4^{\mathrm{T}}$ to use various organic substrates as sole carbon sources at a concentration of $0.4 \%(\mathrm{w} / \mathrm{v})$ was investigated in $5 \mathrm{ml} 5 \%$ SSDM medium. The strain was also characterized using Biolog GN plates according to the method described by Ivanova et al. (1998). Susceptibility of the strain to antibiotics was tested by using $5 \%$ SSDMY agar and $6 \mathrm{~mm}$ sensitivity discs (Tiantan) for the following antibiotics ( $\mu \mathrm{g}$ per disc unless otherwise stated): ampicillin (30), ceftriaxone (30), cefotaxime (30), cephalothin (30), ciprofloxacin (5), clarithromycin (15), clindamycin (2), erythromycin (15), gentamicin (10), penicillin (10 IU), streptomycin (300), tetracycline (30) and vancomycin (30). Strain $\mathrm{P}-4^{\mathrm{T}}$ was positive for catalase, oxidase and urease and hydrolysis of Tween 80 and was negative for DNase and hydrolysis of starch. The strain was facultatively anaerobic and grew under anaerobic conditions by reducing nitrate and nitrite, but did not grow with fumarate, sulfate, ferric iron or $\mathrm{MnO}_{2}$. Other characteristics of strain $\mathrm{P}-4^{\mathrm{T}}$ are listed in the species description. Some features of strain P- $4^{\mathrm{T}}$ are in accordance with those of recognized members of the genus Thalassospira, whereas other features differentiate strain $\mathrm{P}-4^{\mathrm{T}}$ from closely related Thalassospira species. The physiological properties of strain $\mathrm{P}-4^{\mathrm{T}}$ and those of the type strains of Thalassospira species are summarized in Table 1.

Respiratory lipoquinones were extracted and purified as described by Komagata \& Suzuki (1987). The purified ubiquinones were dissolved in acetone and separated by reversed-phase HPLC (Shim-pack VP-OD; Shimadzu). Cellular fatty acid methyl esters were prepared and analysed using gas chromatography according to the instructions of the Microbial Identification System (MIDI). Peaks were integrated automatically and fatty acid names and percentages were determined using the Microbial Identification software (Sasser, 1990). The predominant isoprenoid quinone was Q-9. The results of the cellular fatty acid content analysis are given in Supplementary Table S1 (available in IJSEM Online). The fatty acids making up more than $5 \%$ of the total in strain P-4 ${ }^{\mathrm{T}}$ were $\mathrm{C}_{18: 1} \omega 7 c(35.0 \%), \mathrm{C}_{16: 0}(25.0 \%), \mathrm{C}_{16: 1} \omega 7 c$ $(17.9 \%), \mathrm{C}_{14: 0}(6.2 \%)$ and $\mathrm{C}_{17: 0}$ cyclo $(5.2 \%)$. The predominant fatty acids of strain $\mathrm{P}-4^{\mathrm{T}}$ were similar to those of other recognized species of Thalassospira, although the proportions were different.

The capacity of strain $\mathrm{P}-4^{\mathrm{T}}$ to degrade naphthalene, phenanthrene, anthracene, fluoranthene, pyrene and benzo[a]pyrene was tested in 5\% SSDM culture supplemented with single PAH $\left(100 \mu \mathrm{g} \mathrm{ml}^{-1}\right)$ using HPLC as described previously (Zhao et al., 2009). After 8 days of incubation, strain $\mathrm{P}-4^{\mathrm{T}}$ could degrade naphthalene, phenanthrene and pyrene whereas no degradation occurred on anthracene, fluoranthene or benzo[a]pyrene.

Genomic DNA was extracted and purified by the method of Marmur (1961) and DNA purity was assessed by the
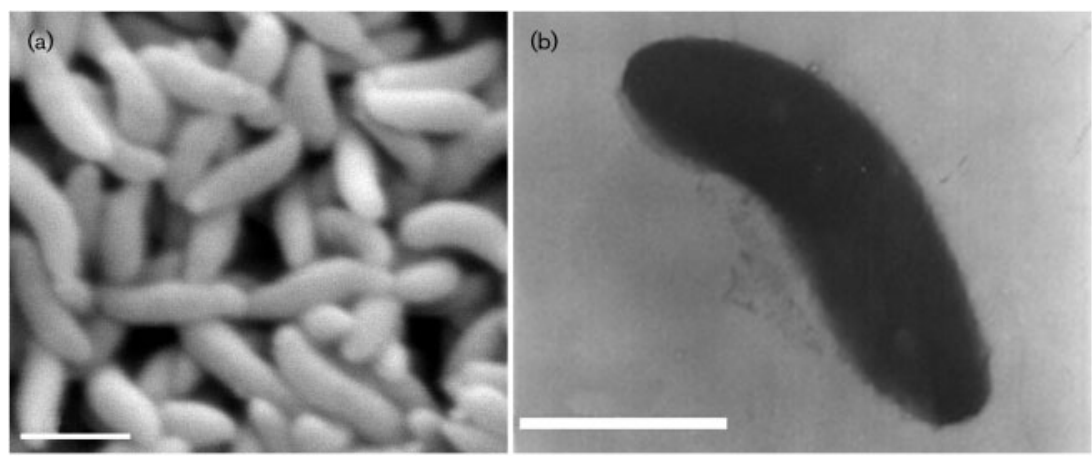

Fig. 1. Electron micrographs of strain $P-4^{\top}$ showing a scanning electron micrograph (a) and electron micrograph of negatively stained cells (b). Bars, $1 \mu \mathrm{m}$. 
Table 1. Differential phenotypic characteristics of strain $P-4^{\top}$ and related type strains of the genus Thalassospira

Strains: 1, Thalassospira xianhensis sp. nov. $\mathrm{P}-4^{\mathrm{T}} ; 2$, T. xiamenensis DSM $17429^{\mathrm{T}} ; 3$, T. profundimaris DSM $17430^{\mathrm{T}} ; 4$, T. lucentensis DSM $14000^{\mathrm{T}}$; 5, T. tepidiphila DSM $18888^{\mathrm{T}}$. Data were taken from this study unless indicated. All strains are positive for catalase and oxidase activities, utilization of L-arabinose, cellobiose, D-fructose, D-mannose, D-glucosaminic acid, $\gamma$-hydroxybutyric acid, DL-lactic acid, L-alanyl glycine, L-alanine, L-glutamic acid and glycerol and acid production from D-galactose and mannose. All strains are negative for utilization of melibiose and D-sorbitol and acid production from arabinose and lactose. +, Positive; w, weakly positive; -, no reaction or growth; ND, no data available.

\begin{tabular}{|c|c|c|c|c|c|}
\hline Characteristic & 1 & 2 & 3 & 4 & 5 \\
\hline Cell shape $e^{\star}$ & $\mathrm{CR}-\mathrm{S}$ & $\mathrm{CR} \dagger$ & $\mathrm{CR} \dagger$ & CR-S† & $\mathrm{v}-\mathrm{S} \dagger$ \\
\hline Flagella $\ddagger$ & - & MS $\dagger$ & $-\dagger$ & $\mathrm{MS} \dagger$ & MS $\dagger$ \\
\hline Pigment\$ & $\mathrm{C}-\mathrm{Y}$ & $\sim \mathrm{Y}$ & $\mathrm{OP}$ & $\sim \mathrm{Y}$ & SY \\
\hline Oxygen requirementll & $\mathrm{FA}$ & $\mathrm{FA} \dagger$ & $\mathrm{FA} \dagger$ & $\mathrm{SA} \dagger$ & $\mathrm{FA} \dagger$ \\
\hline \multicolumn{6}{|l|}{ Growth at: } \\
\hline $4{ }^{\circ} \mathrm{C}$ & + & + & - & + & - \\
\hline $40{ }^{\circ} \mathrm{C}$ & + & + & - & + & + \\
\hline \multicolumn{6}{|l|}{$\begin{array}{l}\mathrm{NaCl} \text { concentration for } \\
\text { growth }(\%)\end{array}$} \\
\hline Range & $0.1-17$ & $0.5-10$ & $2-8$ & $2-10$ & $2-14$ \\
\hline Optimum & $3-6$ & $2-4$ & $3-4$ & ND & 3.0 \\
\hline Reduction of nitrate & + & + & + & - & $+\dagger$ \\
\hline Denitrification & + & + & + & - & $-\dagger$ \\
\hline Hydrolysis of Tween 80 & + & - & + & - & $\mathrm{w}$ \\
\hline \multicolumn{6}{|l|}{ Substrate utilization } \\
\hline Acetic acid & - & - & - & + & + \\
\hline $\begin{array}{l}N \text {-Acetyl-D- } \\
\text { glucosamine }\end{array}$ & + & + & - & + & - \\
\hline cis-Aconitic acid & + & + & - & $\mathrm{w}$ & + \\
\hline$\gamma$-Aminobutyric acid & + & - & - & + & + \\
\hline L-Asparagine & + & + & - & - & + \\
\hline L-Aspartic acid & + & - & - & + & + \\
\hline Citric acid & + & - & - & + & + \\
\hline D-Galactose & + & + & - & + & + \\
\hline D-Galacturonic acid & - & - & $\mathrm{w}$ & $\mathrm{w}$ & $\mathrm{w}$ \\
\hline D-Glucuronic acid & + & - & - & + & + \\
\hline L-Gluconic acid & + & + & + & + & - \\
\hline L-Histidine & + & + & $\mathrm{w}$ & + & + \\
\hline Hydroxy-L-proline & + & + & - & - & + \\
\hline $\begin{array}{l}\text { p-Hydroxyphenylacetic } \\
\text { acid }\end{array}$ & - & - & - & + & - \\
\hline myo-Inositol & + & + & - & + & + \\
\hline Lactose & + & - & - & - & + \\
\hline L-Leucine & - & - & - & $\mathrm{w}$ & - \\
\hline Maltose & + & + & - & + & - \\
\hline D-Mannitol & + & + & + & - & - \\
\hline L-Ornithine & + & + & - & - & - \\
\hline Putrescine & + & - & - & + & - \\
\hline D-Saccharic acid & + & - & - & + & - \\
\hline L-Serine & - & + & - & + & + \\
\hline Sucrose & + & + & - & - & - \\
\hline L-Threonine & - & $\mathrm{W}$ & - & - & - \\
\hline
\end{tabular}

Table 1. cont

\begin{tabular}{|lccccc|}
\hline Characteristic & $\mathbf{1}$ & $\mathbf{2}$ & $\mathbf{3}$ & $\mathbf{4}$ & $\mathbf{5}$ \\
\hline Thymidine & - & + & - & - & - \\
Trehalose & + & + & - & - & - \\
Acid production from: & & & & & \\
D-Fructose & + & + & + & - & - \\
Glucose & + & + & - & + & + \\
Maltose & + & + & + & + & - \\
Mannitol & + & + & + & - & + \\
Sucrose & + & + & - & - & - \\
Xylose & + & + & + & + & - \\
DNA G+C content & $61.2 \pm$ & $52.9 \pm$ & $46.8 \pm$ & $54.4 \pm$ & $53.5 \pm$ \\
(mol\%) & 1.0 & 0.8 & 1.2 & 0.9 & 1.6 \\
\hline
\end{tabular}

${ }^{\star} \mathrm{CR}$, Curved rods; $\mathrm{s}$, spirilla; $\mathrm{v}$, vibrioid.

$\dagger$ Data from Kodama et al. (2008), Liu et al. (2007) and López-López et al. (2002).

¥MS, Monopolar single.

§C, Cream; OP, opalescent; SY, slightly yellow; Y, yellow; $\sim$ Y, yellowish. IIFA, Facultative anaerobe; SA, strict aerobe.

SValues are means $\pm \operatorname{SEM}(n=3)$.

$A_{280} / A_{260}$ ratio (Johnson, 1994). The $16 \mathrm{~S}$ rRNA gene sequence of strain $\mathrm{P}-4^{\mathrm{T}}$ was amplified by PCR as described by Rainey et al. (1992) with universal bacterial primers corresponding to Escherichia coli position 8F (5'AGAGTTTGATCCTGGCTCAG- $\left.3^{\prime}\right)$ and 1492R (5'GGTTACCTTGTTACGACTT-3'). The sequences obtained were compared with reference $16 \mathrm{~S}$ rRNA gene sequences available in the GenBank database. 16S rRNA gene sequence alignments were performed with the CLUSTAL $\mathrm{X}$ program (version 1.64b; Thompson et al., 1997). A phylogenetic tree was constructed using the neighbourjoining and maximum-parsimony methods with MEGA version 3 (Kumar et al., 2004; Saitou \& Nei, 1987). An almost-complete $16 \mathrm{~S}$ rRNA gene sequence (1456 bp) of strain $\mathrm{P}-4^{\mathrm{T}}$ was determined and analysed. Strain $\mathrm{P}-4^{\mathrm{T}}$ showed highest levels of sequence similarity to Thalassospira xiamenensis $\mathrm{M}-5^{\mathrm{T}}(99.2 \%)$, T. profundimaris WP0211 ${ }^{\mathrm{T}}(98.9 \%)$, T. tepidiphila $1-1 \mathrm{~B}^{\mathrm{T}}(98.5 \%)$ and $T$. lucentensis DSM $14000^{\mathrm{T}}(98.0 \%)$. The phylogeny of $16 \mathrm{~S}$ rRNA gene sequences revealed that strain $\mathrm{P}-4^{\mathrm{T}}$ had closest affinity with the recognized species of Thalassospira, with high levels of bootstrap support (Fig. 2).

The G $+\mathrm{C}$ content of genomic DNA was determined by the thermal denaturation method (Gerhardt et al., 1994) using DNA from E. coli K-12 as a control. DNA-DNA hybridization was performed in triplicate by the thermal denaturation and renaturation method (Zakrzewska-Cerwinska et al., 1988). The genomic DNA G $+C$ content of strain $P-4^{T}$ was $61.2 \pm 1.0 \mathrm{~mol} \%$. Strain P-4 $4^{\mathrm{T}}$ exhibited levels of DNA-DNA relatedness of $36.0 \pm 5.2,28.3 \pm 4.8,8.3 \pm 2.3$ and $5.3 \pm 1.2 \%$ with T. xiamenensis DSM $17429^{\mathrm{T}}$, T. tepidiphila DSM $18888^{\mathrm{T}}$, T. profundimaris DSM $17430^{\mathrm{T}}$ and T. lucentensis DSM $14000^{\mathrm{T}}$, respectively (Supplementary Table S2), which are clearly below the $70 \%$ threshold generally accepted for 


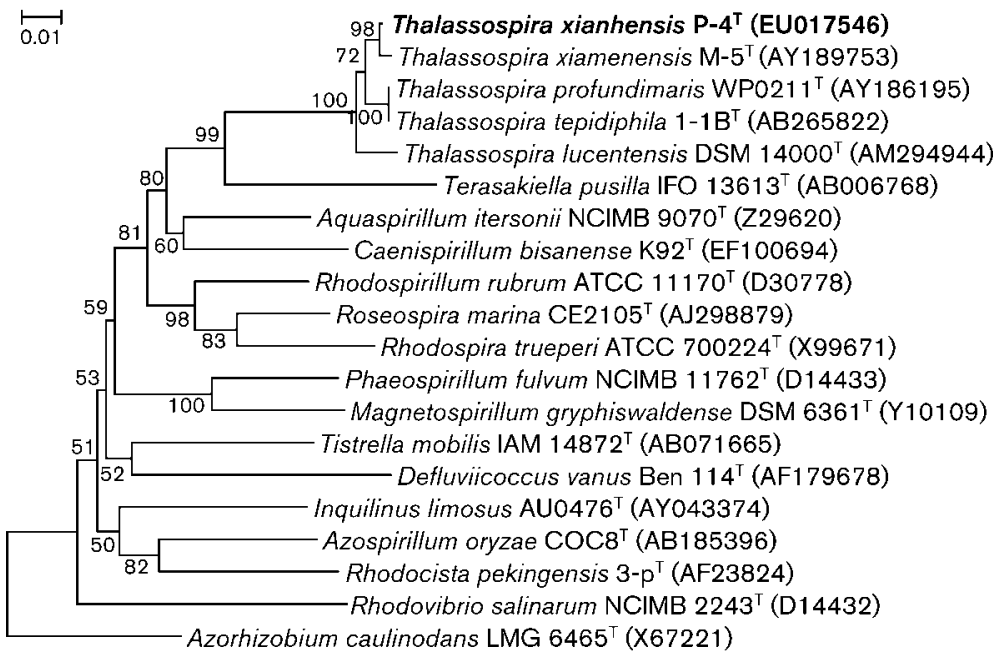

Fig. 2. Phylogenetic tree based on $16 \mathrm{~S}$ rRNA gene sequences showing the relationship between the members of the genus Thalassospira and related genera within the family Rhodospirillaceae. Azorhizobium caulinodans LMG $6465^{\top}$ was used as the outgroup. Bootstrap values $(>50 \%)$ based on 1000 replicates are shown at branch nodes. Bar, $1 \%$ sequence divergence.

species delineation (Wayne et al., 1987; Stackebrandt \& Goebel, 1994).

On the basis of phenotypic, chemotaxonomic and phylogenetic data and genomic distinctiveness, strain $\mathrm{P}-4^{\mathrm{T}}$ should be placed in the genus Thalassospira as a representative of a novel species, for which we propose the name Thalassospira xianhensis sp. nov.

\section{Description of Thalassospira xianhensis sp. nov.}

Thalassospira xianhensis sp. nov. (xian.hen'sis. xianhensis pertaining to Xianhe of Shangdong Province, China, where the type strain was isolated).

Cells are facultatively anaerobic, Gram-negative-staining, curved to spiral rods $(0.3-0.6 \times 1.0-1.6 \mu \mathrm{m})$. Colonies on $5 \%$ SSDMY agar are cream-yellow, circular, smooth, opaque and approximately $1.5-2 \mathrm{~mm}$ in diameter after incubation at $30{ }^{\circ} \mathrm{C}$ for 2 days. Growth occurs at temperatures between $10{ }^{\circ} \mathrm{C}$ and $42{ }^{\circ} \mathrm{C}$ (optimum $30{ }^{\circ} \mathrm{C}$ ), with saline concentrations between 0.1 and $17.0 \%$ (optimum 3.0-6.0\%) and at $\mathrm{pH}$ 5.5-9.0 (optimum $\mathrm{pH}$ 7.2). Positive for catalase, oxidase and urease and hydrolysis of Tween 80 , but negative for DNase and hydrolysis of starch. Facultative anaerobic growth with nitrate and nitrite as electron acceptors. Sensitive to ampicillin, cephalothin, clarithromycin, clindamycin, erythromycin, penicillin and vancomycin, but resistant to ceftriaxone, cefotaxime, ciprofloxacin, gentamicin, streptomycin and tetracycline. Among the 95 carbon sources in the Biolog system, the following are utilized: adonitol, L-arabinose, D-arabitol, cellobiose, i-erythritol, D-fructose, gentiobiose, $\alpha$-D-glucose, $\alpha$-D-lactose, lactulose, D-mannose, raffinose, D-sorbitol, turanose, xylitol, pyruvate methyl ester, D-galactonic acid lactone, D-gluconic acid, D-glucosaminic acid, $\beta$-hydroxybutyric acid, $\alpha$-ketoglutaric acid, DL-lactic acid, malonic acid, quinic acid, D- and L-alanine, L-alanyl glycine, L-glutamic acid, glycyl L-aspartic acid, glycyl L-glutamic acid, bromosuccinic acid, L-proline, L-pyroglutamic acid, urocanic acid and glycerol. Acid is produced from D-fructose, D-glucose, D-galactose, D-xylose, D-mannitol, maltose, mannose and sucrose, but not from lactose or arabinose. The predominant respiratory quinone is Q-9. The major fatty acids are $\mathrm{C}_{18: 1} \omega 7 c, \mathrm{C}_{16: 0}, \mathrm{C}_{16: 1} \omega 7 c$, $\mathrm{C}_{14: 0}$ and $\mathrm{C}_{17: 0}$ cyclo, with smaller amounts of $\mathrm{C}_{16: 0} 3-\mathrm{OH}$, $\mathrm{C}_{18: 0}$ and $\mathrm{C}_{14: 0} 3-\mathrm{OH}$. The genomic DNA $\mathrm{G}+\mathrm{C}$ content of the type strain is $61.2 \pm 1.0 \mathrm{~mol} \%$.

The type strain, P-4 $4^{\mathrm{T}}$ (=CGMCC $1.6849^{\mathrm{T}}=\mathrm{JCM} 14850^{\mathrm{T}}$ ) was isolated from a saline soil contaminated by crude oil, collected from Xianhe, Shangdong Province, China.

\section{Acknowledgements}

We would like to thank I. D. Wagner (University of Georgia) for having carefully read the manuscript. This research was supported by the National Natural Science Foundation of China (nos 30700023, 30970098 and 20737001) and the special fund of the State Key Joint Laboratory of Environmental Simulation and Pollution Control (nos 08Z03ESPCT and 09Y03ESPCT).

\section{References}

Acinas, S. G., Antón, J. \& Rodríguez-Valera, F. (1999). Diversity of free-living and attached bacteria in offshore western Mediterranean waters as depicted by analysis of genes encoding 16S rRNA. Appl Environ Microbiol 65, 514-522.

Baron, E. J. \& Finegold, S. M. (1990). Bailey and Scott's Diagnostic Microbiology, 8th edn. St Louis: Mosby.

Cowan, S. T. \& Steel, K. J. (1965). Manual for the Identification of Medical Bacteria. London: Cambridge University Press.

Gerhardt, P., Murray, R. G. E., Wood, W. A. \& Krieg, N. R. (editors) (1994). Methods for General and Molecular Bacteriology. Washington, DC: American Society for Microbiology.

Guerin, W. F. \& Jones, G. E. (1988). Two-stage mineralization of phenanthrene by estuarine enrichment cultures. Appl Environ Microbiol 54, 929-936.

Habe, H. \& Omori, T. (2003). Genetics of polycyclic aromatic hydrocarbon metabolism in diverse aerobic bacteria. Biosci Biotechnol Biochem 67, 225-243. 
Hedlund, B. P. \& Staley, J. T. (2001). Vibrio cyclotrophicus sp. nov., a polycyclic aromatic hydrocarbon $(\mathrm{PAH})$-degrading marine bacterium. Int J Syst Evol Microbiol 51, 61-66.

Ivanova, E. P., Kiprianova, E. A., Mikhailov, V. V., Levanova, G. F., Garagulya, A. D., Gorshkova, N. M., Vysotskii, M. V., Nicolau, D. V., Yumoto, N. \& other authors (1998). Phenotypic diversity of Pseudoalteromonas citrea from different marine habitats and emendation of the description. Int J Syst Bacteriol 48, 247-256.

Johnson, J. L. (1994). Similarity analysis of DNAs. In Methods for General and Molecular Bacteriology, pp. 655-681. Edited by P. Gerhardt, R. G. E. Murray, W. A. Wood \& N. R. Krieg. Washington, DC: American Society for Microbiology.

Kasai, Y., Kishira, H. \& Harayama, S. (2002). Bacteria belonging to the genus Cycloclasticus play a primary role in the degradation of aromatic hydrocarbons released in a marine environment. Appl Environ Microbiol 68, 5625-5633.

Kodama, Y., Stiknowati, L., Ueki, A., Ueki, K. \& Watanabe, K. (2008). Thalassospira tepidiphila sp. nov., a polycyclic aromatic hydrocarbondegrading bacterium isolated from seawater. Int J Syst Evol Microbiol 58, 711-715.

Komagata, K. \& Suzuki, K. (1987). Lipid and cell-wall analysis in bacterial systematics. Methods Microbiol 19, 161-207.

Kumar, S., Tamura, K. \& Nei, M. (2004). MEGA3: integrated software for molecular evolutionary genetics analysis and sequence alignment. Bioinformatics 5, 150-163.

Kwon, K. K., Lee, H. S., Yang, S. H. \& Kim, H. J. (2005). Kordiimonas gwangyangensis gen. nov., sp. nov., a marine bacterium isolated from marine sediments that forms a distinct phyletic lineage (Kordiimonadales ord. nov.) in the 'Alphaproteobacteria'. Int J Syst Evol Microbiol 55, 2033-2037.

Lányí, B. (1987). Classical and rapid identification methods for medically important bacteria. Methods Microbiol 19, 1-67.

Liu, C., Wu, Y., Li, L., Ma, Y. \& Shao, Z. (2007). Thalassospira xiamenensis $\mathrm{sp}$. nov. and Thalassospira profundimaris sp. nov. Int $J$ Syst Evol Microbiol 57, 316-320.

López-López, A., Pujalte, M. J., Benlloch, S., Mata-Roig, M., Rosselló-Mora, R., Garay, E. \& Rodríguez-Valera, F. (2002). Thalassospira lucentensis gen. nov., sp. nov., a new marine member of the $\alpha$-Proteobacteria. Int J Syst Evol Microbiol 52, 1277-1283.
Marmur, J. (1961). A procedure for the isolation of deoxyribonucleic acid from microorganisms. J Mol Biol 3, 208-218.

Menzie, C. A., Potocki, B. B. \& Santodonato, J. (1992). Exposure to carcinogenic PAHs in the environment. Environ Sci Technol 26, 12781284.

Rainey, F. A., Dorsch, M., Morgan, H. W. \& Stackebrandt, E. (1992). $16 \mathrm{~S}$ rDNA analysis of Spirochaeta thermophila: position and implications for the systematics of the order Spirochaetales. Syst Appl Microbiol 16, 197-202.

Saitou, N. \& Nei, M. (1987). The neighbor-joining method: a new method for reconstructing phylogenetic trees. Mol Biol Evol 4, 406-425.

Sasser, M. (1990). Identification of bacteria by gas chromatography of cellular fatty acids, MIDI Technical Note 101. Newark, DE: MIDI Inc.

Sohn, J. H., Kwon, K. K., Kang, J. H., Jung, H. B. \& Kim, H. J. (2004). Novosphingobium pentaromativorans sp. nov., a high-molecular-mass polycyclic aromatic hydrocarbon-degrading bacterium isolated from estuarine sediment. Int J Syst Evol Microbiol 54, 1483-1487.

Stackebrandt, E. \& Goebel, B. M. (1994). Taxonomic note: a place for DNA-DNA reassociation and $16 \mathrm{~S}$ rRNA sequence analysis in the present species definition in bacteriology. Int J Syst Bacteriol 44, 846-849.

Thompson, J. D., Gibson, T. J., Plewniak, F., Jeanmougin, F. \& Higgins, D. G. (1997). The CLUSTAL_X windows interface: flexible strategies for multiple sequence alignment aided by quality analysis tools. Nucleic Acids Res 25, 4876-4882.

Wayne, L. G., Brenner, D. J., Colwell, R. R., Grimont, P. A. D., Kandler, O., Krichevsky, M. I., Moore, L. H., Moore, W. E. C., Murray, R. G. E. \& other authors (1987). International Committee on Systematic Bacteriology. Report of the ad hoc committee on reconciliation of approaches to bacterial systematics. Int J Syst Bacteriol 37, 463-464.

Zakrzewska-Cerwinska, J., Mordarski, M. \& Goodfellow, M. (1988). DNA base composition and homology values in the classification of some Rhodococcus species. J Gen Microbiol 134, 2807-2813.

Zhao, B., Wang, H., Mao, X. \& Li, R. (2009). Biodegradation of phenanthrene by a halophilic bacterial consortium under aerobic conditions. Curr Microbiol 58, 205-210.

Zumft, W. G. (1992). The denitrifying bacteria. In The Prokaryotes: a Handbook on the Biology of Bacteria, 2nd edn, pp. 554-582. Edited by A. Balows, H. G. Trüper, M. Dworkin, W. Harder \& K. H. Schleifer. New York: Springer. 